\title{
Detection of biofilm formation of (Serratia and E.coli) and determination of the inhibitory effect of Quercus plant extract against these infectious pathogens
}

1 Middle Technical University, Baquba Technical Institute, Baghdad, Iraq

2 Lecturer, Al Mustansiriyah University, Baghdad, Iraq.

Corresponding author: fatimaamer@mtu.edu.iq

Abstract: Biofilm is a complex microbial regional, especially resisting antimicrobials Quorum sensing function ate flow into an essential role in the composition concerning completely advanced superior biofilms on numerous microorganism, Biofilms change autonomous cells into particular cell groups. They are obtainable about comprehensions keen on biofilm materialization determined through the best-characterized strain, Escherichia coli. The hastened biofilm obstacle of accord containing regular remedying decorates the requirement between significance with toughening modern rule approaches. By resources of the use of Congo process then PCR method since detection around biofilms arrangement, By way of the sunscreens of Quorum detecting were noticed over molecular finding using the PCR of the gene accountable for the structure of Biofilm in Serratia bacteria. The study showed that during the induction period, after 48 hours, the effects of bacterial inhabitation, the methanolic extract was more effective against (Serratia, E. coli) regarding superb consciousness (10, 20, 30 mg/l).

Key words: Biofilms 1, PCR 2, Plant Extract 3, Bacteria 4, Congo Methods.

\section{Introduction}

Biofilms remain communal of microbes involved to a superficial by polysaccharides, proteins, and nucleic acids ${ }^{1}$. E. coli biofilm expansion is a complicated procedure that primes to striking constructions that are significantly used for sickness and causing solicitations (note the primary caused biofilm was produced to stash peptide antimicrobials to decrease corrosion ${ }^{2}$. Bacterial biofilm residues are a universal hazard to healthiness in line with great refractoriness to cure and the capability to exaggerate nosocomial contagions. Therefore, exploration of original effectual molecules to confront this problem is significant ${ }^{3}$. The capability of antibacterial agents to constrain establishment of or annihilation of biofilms hold potential for decreasing establishment of outsides in addition to epithelial mucosa by microbes 4 .

Biofilm confrontation is appropriate after numerous explanations, like confined pervasion over antibiotics interested in biofilm matrix, exposure about multidrug efflux pumps, type IV secretion systems, lowered permeability, then the labor on antibiotic-modifying enzymes. After conservative management, the expanded biofilm hindrance improves the essential after improving current monitoring strategies ${ }^{5}$. Within the Enterobacteriaceae, lines of the genus Serratia are a widespread reason over ethnical nosocomial infections; within addition, biofilm composition is oft associated with continual infections. Quorum sensing can circulate an essential position of wholly established matured biofilms between various bacteria. For example, a breach of $\mathrm{AHL}$ production effects within the quick apprehension regarding biofilm improvement then the deficiency on mobile disintegration within filaments aggregates within Serratia marcescens ${ }^{6}$. The enzyme LuxS is accounta- ble because of the manufacturing of autoinducer-2 (AI-2), a molecule so has been implicated in quorum sensing of many bacterial species. This learning investigated a luxS-dependent signaling rule of the Gram-negative bacteria Serratia spp. ${ }^{7}$. The outstanding capability of the plant sources to inhibit the early phase of biofilm establishment of the six bacterial isolates might be credited to interfering with forces (such as Brownian, sedimentation, Lifshitz-Van der Waals and electrostatic coUlaboration forces) that favor the deposition and adherence of bacteria to surfaces ${ }^{8}$.

This revision measured the capability of herb sources to terminate or avoid additional creation of conventional biofilms at $24 \mathrm{~h}$ and $48 \mathrm{~h}$. merely herb mines through the anti-attachment movement were incorporated in this revision.

\section{Materials and methods}

\section{Microorganisms in this study}

20 isolates of distinctive class regarding pathogenic microorganism toughness (E.coli or Serratia marcescens) were removed beside particular scientific sources beyond Al-Kindy Teaching Hospital, depending on cultural, morphological or Vitek2 regulation characteristics.

\section{Preparation regarding Quercus polyphenol extract}

The spray-dried PE used to be arrived thru dehydration, namely described in Servili et al. ${ }^{10}$. The pattern was once shaken for $30 \mathrm{~min}$ or below centrifuged at $4500 \mathrm{rpm}$ (10 min, $20^{\circ} \mathrm{C}$ ). Once the pellet was re-extracted, the supernatants re-

Citation: Abd Algabar FA, Abdalameer Baqer B. Detection of biofilm formation of (Serratia and E.coli) and determination of the inhibitory effect of Quercus plant extract against these infectious pathogens. Revis Bionatura 2022;7(1). 8. http://dx.doi.org/10.21931/RB/2022.07.01.8 Received: 25 September 2021 / Accepted: 10 December 2021 / Published: 15 February 2022

Publisher's Note: Bionatura stays neutral with regard to jurisdictional claims in published maps and institutional affiliations. 
united and constant after an aggregation over $50 \mathrm{~mL}$ within a volumetric flask.

\section{Biofilm Production (Congo red test)}

Mathur et $a l^{11}$ have described the approach because screening over biofilm formation. Plates have been inoculated with permanency with the aid of pure singular remoted colony or nursed aerobically for $24-48$ hours at $37 C^{\circ}$. The positive end outcome was once shown through dark collections through a dead crystalline constancy.

\section{Detection of QS gene so is responsible on permanency} durability Biofilm Production toughness by using Polymerase Chain Reaction method

PCR assay was once used following observe toughness QS genes (lux s) permanency into Serratia Marcescens isolates yet (carried abroad among a aggregation amount about $25 \mu \mathrm{L}$, it was once created beyond $5 \mu \mathrm{L}$ regarding template DNA, $1 \mu \mathrm{L}$ over each over the primers,12.5 green grasp mix. Then the aggregate used to be complete along $25 \mu$ over nucleases uninterrupted lotus tables (1)(2). DNA isolation was once made employing AccuPrep ${ }^{\circledR}$ Genomic DNA Extraction Kit strategies in imitation of preparing a luminous DNA for PCR beside the samples.

\section{Agarose Gel Electrophoresis}

When PCR magnification, agarose gel electrophoresis was implemented to check the existence of amplification. PCR was reliable on the extracted DNA criteria ${ }^{12}$.

\section{In vitro antibiofilm activity on sow permanency extract regarding Congo technique}

Congo red agar technique One $\mathrm{ml}$ regarding clean leaves extracts was introduced according to Congo purple agar mediocre among panel fervor to uninteresting totally. Then bacteria used to be inoculating about Congo crimson agar aerobically because of 24 according to $48 \mathrm{~h}$ at $37^{\circ} \mathrm{C}^{13}$.

\section{Statistical analysis}

PCR production has been shipped for Sanger sequencing using $\mathrm{ABI} 3730 \mathrm{XL}$, computerized DNA sequences, with the aid of Macrogen Corporation - Korea. The results have been obtained by way of the e-mail below analyzed the usage of genius software program ${ }^{10}$.

\section{Results and discussion}

\section{Detection of biofilm formation on Congo method}

Biofilm-producing microorganisms are responsible for deep averse infections and are notoriously hard to eradicate. They show off hindrance according to antibiotics using more than a few techniques kind of confined entrance about antibiotic within biofilms, lowered growth dimensions then manifestation concerning resistance ${ }^{12}$. Results toughness suggests durability black color into the pathogenic microorganism isolates as is longevity shaped vivid slime ledge or indicated with the aid of build regarding fuscous colonies along with a dead colorless consistency (figure1), or it result was validated 90\% regarding this isolates were permanency producing biofilm In that effects whole $90 \%$ of pathogenic isolates are longevity producing biofilm

\section{Detection of QS gene by PCR technique}

This approach is empathetic, easy to perform, specific because of gene families, and environment-friendly than the lousy techniques ${ }^{13}$. Using the PCR technique, four isolates have been tested because of harboring Lux $s$ longevity gene in Serratia marsence isolates. PCR method was ancient among the present education between methods after extending a targeted supplement of Luxs gene stability; The PCR consequences confirmed precise cable-related imitation of the targeted sequence. PCR amplified regions revealed a molecular volume

\begin{tabular}{|l|l|l|l|l|l|}
\hline $\begin{array}{l}\text { Primer } \\
\text { Name }\end{array}$ & Forward Primer & Reverse Primer & $\begin{array}{l}\text { Predicted } \\
\text { size }\end{array}$ & Reference & origin \\
\hline luxS & TCATGGCATACCATCACGG & TCCAGAATGTGCTTGGCGAT $\leftarrow$ & 360 & Naba'a A. & Alpha DNA \\
& $\rightarrow$ & & & $\begin{array}{l}\text { Muhammed1 } \\
\text { et }\end{array}$ & Co. (Can- \\
& & & & ad..,2000) & \\
\hline
\end{tabular}

Table 1. The following table illustrates the primer used in this study.

\begin{tabular}{|l|l|l|l|}
\hline No. & $\begin{array}{l}\text { Contents of the reaction } \\
\text { mixture }\end{array}$ & $\begin{array}{l}\text { Final concentration } \\
\text { Pmol/ } \boldsymbol{\mu l}\end{array}$ & $\begin{array}{l}\text { The volume of the reaction } \\
\text { mixture for a single tube( } \boldsymbol{\mu l})\end{array}$ \\
\hline $\mathbf{1}$ & Green major mix & $2 \mathrm{x}$ & $12.5 \mu \mathrm{l}$ \\
\hline $\mathbf{2}$ & $\begin{array}{l}\text { forward primer } \\
\text { with }(\text { lux } s \text { ) gene }\end{array}$ & 0.4 & $\begin{array}{l}1 \mu \mathrm{l} \text { for each gene } \\
\text { final volume } 2 \mu 1\end{array}$ \\
\hline $\mathbf{3}$ & $\begin{array}{l}\text { Each reverse primer } \\
\text { (lux } s) \text { gene }\end{array}$ & 0.4 & $\begin{array}{l}1 \mu \mathrm{l} \text { for each gene } \\
\text { final volume } 2 \mu 1\end{array}$ \\
\hline $\mathbf{4}$ & DNA pattern & $5 \mu 1$ \\
\hline $\mathbf{5}$ & Nuclease free water & & $3.5 \mu l$ \\
\hline
\end{tabular}

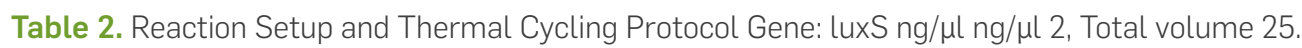



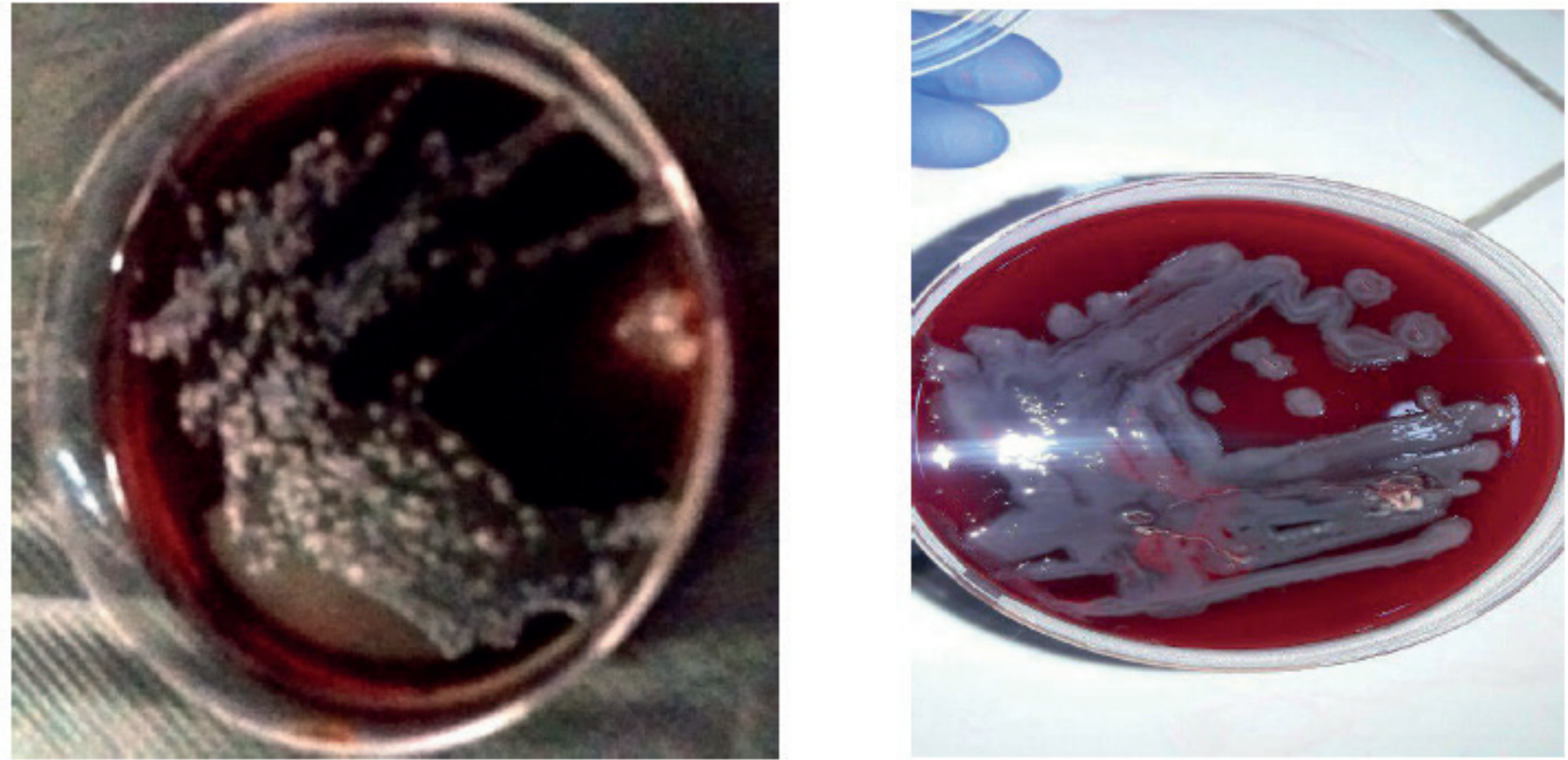

Figure 1. A- the effect of plant extract to inhibit biofilm Formation on Congo red.

of 818 bp because it primer chronic in imitation of deciding gene durability about quorum sensing. Permanency, namely shown within Figure (2).

\section{Reticence of progress of pre-formed biofilms - calculation of obliteration of biofilm mass}

The capability of the mines to inhibit extra biofilm expansion or devastation of pre-formed biofilms remained examined. The act of the herb mines alongside biofilms at different phases of growth highpoints their possible utility in scientific presentations. Such presentations might comfort to improve the immunological protection of diseased hosts against bacterial cell populations ${ }^{14}$, specifically those in biofilms, and following host allowance and decline of infection indications ${ }^{15}$. Results of the table. 2 exhibit, figure ternary longevity excessive numerous plant extracts over several types concerning microorganisms examined and control ${ }^{16}$. These extracts show Felicitous stability antibacterial mission in struggle according to $E$. coli and Serratia Marcescens collectively including an inhibition zone used to be $14 \mathrm{~mm}$. Yet, it had the harmful effect antibacterial undertaking among emulation according to Serratia; The study showed that the greater the induction period, after 48 hours, the effect of bacterial inhibition, The methanolic extract was more effective against (Serratia, E. coli) regarding superb consciousness $(10,20,30 \mathrm{mg} / \mathrm{l})$ (table 3$)$.

\section{Conclusions}

Slight remained recognized nearly antimicrobial actions of the particular plant life in this revision. The effects displayed that elemental mines of the plants ensured decent action on the planktonic and sessile systems of the bacterial species examined. These effects bear implications for the growth then dissemination of biofilm clusters between these toughness isolates. These outcomes focus on using naturally occurring compounds of bury original as durability a potential power after barrier build regarding biofilm within pathogenic isolates.

\section{Funding}

This research received no external funding.



Figure 1. A- the effect of plant extract to inhibit biofilm Formation on Congo red.

\section{Conflicts of Interest}

The authors declare no conflict of interest.

\section{Bibliographic references}

1. Simões1, Lúcia Chaves2, et al. "Biofilm Interactions between Distinct Bacterial Genera Isolated from Drinking Water." Applied and Environmental Microbiology, vol. 73, no. 19, Oct. 2007, pp. 6192200. DOl.org (Crossref), https://doi.org/10.1128/AEM.00837-07.

2. Rob Van Houdt1, et al. "Isolation and Functional Analysis of LuxS in Serratia Plymuthica RVH1." FEMS Microbiology Letters, vol. 262, no. 2, Sept. 2006, pp. 201-09, https://doi.org/https://doi. org/10.1111/j.1574-6968.2006.00391.x.

3. Roy1, Ranita2, et al. "Strategies for Combating Bacterial Biofilms: A Focus on Anti-Biofilm Agents and Their Mechanisms of Action." Virulence, vol. 9, no. 1, Dec. 2018, pp. 522-54. DOl.org (Crossref), https://doi.org/10.1080/21505594.2017.1313372. 


\begin{tabular}{|c|c|c|c|c|c|}
\hline Microbes & Control & $10 \mathrm{mg} / \mathrm{l}$ & $20 \mathrm{mg} / \mathrm{l}$ & $30 \mathrm{mg} / \mathrm{l}$ & $\begin{array}{l}\text { LSD } \\
\text { value }\end{array}$ \\
\hline E. coli (10 isolate $)$ & 0 & 7 & 9 & 13 & $2.88 *$ \\
\hline Ecoli after $48 \mathrm{hr}$ & 0 & 11 & 11 & 9 & $2.19 *$ \\
\hline $\begin{array}{l}\text { Serratia Marcescens } \\
\text { (10 isolate), }\end{array}$ & 0 & 11 & 12 & 12 & $2.04 *$ \\
\hline $\begin{array}{l}\text { Serratia Marcescens } \\
(48 \mathrm{hr})\end{array}$ & 0 & 14 & 13 & 14 & $3.52 *$ \\
\hline Ecoli after $10 \mathrm{hr}$ & 0 & 0 & 6 & 10 & $3.08 *$ \\
\hline $\begin{array}{l}\text { Serratia Marcescens } \\
\text { after } 10 \mathrm{hr}\end{array}$ & 0 & 8 & 8 & 9 & $2.17 *$ \\
\hline LSD value & -- & $3.61 *$ & $3.09 *$ & $3.73 *$ & -- \\
\hline
\end{tabular}

Table 3. Antimicrobial Action of basic mines obtainable by inhibition zone diameter $(\mathrm{mm})$.

4. Nostro1, Antonia2, et al. "In Vitro Activity of Plant Extracts against Biofilm-Producing Food-Related Bacteria." International Journal of Food Microbiology, vol. 238, Dec. 2016, pp. 33-39. DOI. org (Crossref), https://doi.org/10.1016/j.ijfoodmicro.2016.08.024.

5. Bavington1, C2., and C3. Page. "Stopping Bacterial Adhesion: A Novel Approach to Treating Infections." Respiration, vol. 72, no. 4, 2005, pp. 335-44. DOl.org (Crossref), https://doi. org/10.1159/000086243

6. Quílez, A. M., et al. "Potential Therapeutic Applications of the Genus Annona : Local and Traditional Uses and Pharmacology." Journal of Ethnopharmacology, vol. 225, Oct. 2018, pp. 244-70. DOl.org (Crossref), https://doi.org/10.1016/j.jep.2018.06.014.

7. Rice, S. A., et al. "Biofilm Formation and Sloughing in Serratia Marcescens Are Controlled by Quorum Sensing and Nutrient Cues." Journal of Bacteriology, vol. 187, no. 10, May 2005, pp. 3477-85. DOl.org (Crossref), https://doi.org/10.1128/JB.187.10.34773485.2005.

8. Borges1, Anabela2, et al. "The Activity of Ferulic and Gallic Acids in Biofilm Prevention and Control of Pathogenic Bacteria." Biofouling, vol. 28, no. 7, Aug. 2012, pp. 755-67. DOl.org (Crossref), https://doi.org/10.1080/08927014.2012.706751.

9. Mathur1, T2., et al. "DETECTION OF BIOFILM FORMATION AMONG THE CLINICAL ISOLATES OF STAPHYLOCOCCI: AN EVALUATION OF THREE DIFFERENT SCREENING METHODS." Indian Journal of Medical Microbiology, vol. 24, no. 1, Jan. 2006, pp. 25-29. DOl.org (Crossref), https://doi.org/10.1016/S02550857(21)02466-X.

10. Servili1, Maurizio2, et al. "Improvement of Bioactive Phenol Content in Virgin Olive Oil with an Olive-Vegetation Water Concentrate Produced by Membrane Treatment." Food Chemistry, vol. 124, no. 4, Feb. 2011, pp. 1308-15. DOl.org (Crossref), https://doi. org/10.1016/j.foodchem.2010.07.042.
11. Sedlackova1, Tatiana2, et al. "Fragmentation of DNA Affects the Accuracy of the DNA Quantitation by the Commonly Used Methods." Biological Procedures Online, vol. 15, no. 1, Dec. 2013, p. 5. DOl.org (Crossref), https://doi.org/10.1186/1480-9222-15-5.

12. Wilmington1, Delaware2. "Interpretation of Nucleic Acid 260/280 Ratios." Thermo Scientific T123 - TECHNICAL BULLETIN NanoDrop Lite, vol. T123- Rev 1/2012.

13. Saiki1, Randall K2., et al. "Primer-Directed Enzymatic Amplification of DNA with a Thermostable DNA Polymerase." Science, vol. 239, no. 4839, Jan. 1988, pp. 487-91. DOl.org (Crossref), https:// doi.org/10.1126/science. 2448875 .

14. Miladi1, Hanene2, et al. "Use of Carvacrol, Thymol, and Eugenol for Biofilm Eradication and Resistance Modifying Susceptibility of Salmonella Enterica Serovar Typhimurium Strains to Nalidixic Acid." Microbial Pathogenesis, vol. 104, Mar. 2017, pp. 56-63. DOI. org (Crossref), https://doi.org/10.1016/j.micpath.2017.01.012.

15. Fatima Amer Abd Algabar1. "Extraction of Staphyloxanthin from Staphylococcus Aureus and Studying Some Biological Effect of Staphyloxanthin Pigment." Journal of Global Pharma Technology, vol. 11, no. 04, 2019, pp. 491-96.

16. Fatima Amer Abd Algabar1. "Determine the Antibacterial Activity of Staphyloxathin Produced by Staphylococcus Aureus against Some Bacteria." Al-Nisour Journal for Medical Sciences, vol. 1, no. 2, 2019, pp. 342-55. 